\title{
Racist apologism and the refuge of nation
}

\section{Sivamohan Valluvan}

To cite this article: Sivamohan Valluvan (2021): Racist apologism and the refuge of nation, Ethnic and Racial Studies, DOI: 10.1080/01419870.2021.1889634

To link to this article: https://doi.org/10.1080/01419870.2021.1889634

$$
\begin{aligned}
& \text { (c) } 2021 \text { The Author(s). Published by Informa } \\
& \text { UK Limited, trading as Taylor \& Francis } \\
& \text { Group }
\end{aligned}
$$

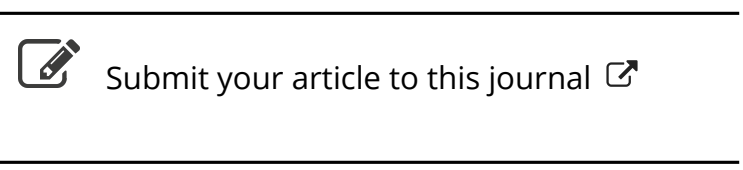

III Article views: 263

Q View related articles $\widetilde{ }$

View Crossmark data \lceil 


\title{
Racist apologism and the refuge of nation
}

\author{
Sivamohan Valluvan \\ University of Warwick, Coventry, UK
}

\begin{abstract}
This symposium commentary on Alana Lenin's Why Race Still Matters considers the terms by which apologists of racism deploy the alibi of nation and (white) identity. The increasingly efficacious claim to 'mere' nationhood and the allegedly organic immutability of majoritarian identity both enables racism whilst impugning anti-racism. Attention will be given here to the chicanery by which racism often ceases to something to be ideologically justified or defended; but instead, the demands of anti-racism are simply deflected through asserting the seemingly superseding dictates of national righteousness. My commentary also speculates about certain connections between the white majority settings surveyed by Lentin and wider postcolonial settings where comparable politics of bordering, chauvinism and 'racial capitalist' stratification are pursued but without the same overarching reference to whiteness.
\end{abstract}

KEYWORDS Racism; nationalism; whiteness; majoritarianism; post-racial; Brexit

\section{On "Why Race Still matters" - Sivamohan Valluvan}

Lentin's (2020) Why Race Still Matters is in its most immediate sense a bracing corrective to the simplifications and elisions that plague commonsensical and officially sanctioned conceptions of racism. A series of characterizations abound today that narrow our understanding of racism's continued centrality to white majoritarian societies. Consider here the routine ascription of racism as an "attitudinal" (66) and individualized problem, or even just a problem of etiquette and courtesy. Or consider the characterization of racism as distinctly anomalous to the wider motions of modern history. This being a racism-asaberration premise that leads to the habitual treatment of racism as essentially a problem of theodicy and evil (64) - as opposed to an accrued set of state practices, discursively embedded assumptions, and also everyday perceptions that guide both governance but also our popular conceptions of

CONTACT Sivamohan Valluvan S.Valluvan@warwick.ac.uk

This article has been republished with minor changes. These changes do not impact the academic content of the article.

(c) 2021 The Author(s). Published by Informa UK Limited, trading as Taylor \& Francis Group

This is an Open Access article distributed under the terms of the Creative Commons Attribution-NonCommercial-NoDerivatives License (http://creativecommons.org/licenses/by-nc-nd/4.0/), which permits non-commercial re-use, distribution, and reproduction in any medium, provided the original work is properly cited, and is not altered, transformed, or built upon in any way. 
identity, community and general subjectification. Why Race Still Matters debunks herein with an easy and accessible prose these insistent myths, myths that circumscribe the scope of justice just as it allows for racisms' well-trammeled paths to be extended into the present.

Why Race Still Matters is on these terms an invitation for mainstream punditry and scholarship to become more "literate" (174) in racisms' more expansive logics and histories. Or, construed along slightly different lines, the book is best seen as an affirmation of an anti-racist commitment, a commitment that firmly refuses its co-option or thinning when touched by the imperatives of branded corporate capitalism, liberal tinkering, or diversity-management oriented technocratic centrism alike. Of course, by equal measure, the general contours of the arguments staked here will feel familiar to those who have already been trained in the particulars of racism's long reach - particularly in its "post-racial", settler-colonial and also nationalist modalities. Modalities that Lentin herself has been central to documenting over the last two decades, not least in her co-authored (Lentin and Titley 2011) The Crises of Multiculturalism. A book that remains, in terms of my own education at least, a landmark text that so presciently captured the emergent political frames of the early 2000s that would later consolidate itself to such winning effect in the next decade.

However, amidst the broader interrogation of mainstream simplifications and elisions, there are also some eminently conjunctural themes that lend Lentin's book a particularly juicy and at times combative complexity. This being a complexity that attends to issues that go beyond mere mainstream naivetes but point towards troubles that the entire task of anti-racism currently contends with.

\section{Race apologia}

This includes, for instance, the terms by which an emphatically conservative political commentariat has managed to claim the mantle of anti-racism via their putative commitment to an "anti-antisemitism" (136) premise. That there is a shameless opportunism here is self-evident. But Lentin is also right to note how this co-option has also yielded an increasingly fraught terrain as regards a conventionally antiracist reckoning with antisemitism [see also Richmond (2020)]. Lentin advances, in turn, a welcome affirmation of the importance of anti-racist attentiveness to antisemitism, reminding us how antisemitism remains a key preoccupation of the new right, particularly in its reheated conspiracist, "anti-globalist" (141) idioms. But this is also a reaffirmation, where Lentin draws upon her own Jewish background, that refuses to accept the insistent terms by which Jewish identity is increasingly seen as coterminous with a pro-Israel investment and where such a political taxonomy helps launder today's assorted Islamophobias with a faux philosemitic alibi. 
Lentin's ability to wrestle with the knots of the contemporary also includes, no less topically, the alleged excesses of certain identitarian-led approaches to anti-racism. An excess that Lentin suggests is overstated if still, in itself, problematic or self-defeating. Lentin's relatively sanguine take here on the place of identity in organizing anti-racist consciousness is not beyond critique. For instance, I am not so sure that these problems are simply contained to the salon culture of fringe academia as Lentin intimates. These being problems that span the reheated essentialisms that appeal to the authenticity of identity and voice (Táíwò 2020); the circulation of often generic, flattening and de-classed critiques of white privilege, fragility, and allyship, etc. as well as the recourse to unduly rigid binaries of insider-outsider, inclusionexclusion, and oppressor-victimhood that can at times obscure more than it reveals about the shape of contemporary socioeconomic and sociocultural locations. These being obfuscating binaries that also risk decentring critical attention from the harder, more explicitly dehumanizing edges of the contemporary "racial state" (Goldberg 2015) - be this the making of war, incarceration, the border and the wider structuring of labour exploitation and disposability. These are also tendencies that can seem largely uninterested in the political but also cultural questions of how new majorities, new nonminoritarian conceptions of future community might be affirmatively forged (Bhattacharyya 2020; Kumar et al. 2018).

But Lentin is still right that reductive class-first approaches and/or impulsive dismissals of minority-led claims to identity risks absolving or, at the very least, risks being "distracted" (109) from the superseding politics of identity that spur those defensive minoritarian claims in the first place. Put differently, it is a white nationalist identity that commands our political sphere. Most claims to minoritarian racial identity are accordingly a reactive, distinctly epiphenomenal response to an estrangement from that hegemonic politics of exclusionary whiteness (Mbembe 2017, 183). As such, whilst I am likely more wary than Lentin of identity's outsized ability to shape anti-racist consciousness, and critical politics more generally, her impatience with the more pervasive decrying of so-called "identity politics" is of course warranted. Indeed, less than sincere critics seem intent on perceiving the specter of identity through a camera obscura. Such liberal and/or unreconstructed Marxist critics hold only the minoritarian expression of identity to account, refusing to interrogate the very majoritarian white identitarianism from which that minoritarian assertion emerges as a prospectively resistant, if limited, invitation. In other words, not all "identity politics" are created equal (Clifford 2000), and I would second Lentin's intimation that a failure to retain that basic sensitivity bespeaks less a frustration with the purported undoing of critical solidarities and more a dangerous, bad faith attempt to decry anti-racist politics tout court. A hostility or indifference that happily exculpates the wider social frame of its endemic and emphatically normative identitarianism. 
But particularly exacting in terms of Lentin's more distinctly contemporary engagements is the attention given to a wider genre of commentary and political positioning where racism is given the ennobling dignity of ethnonationalism. What Lentin calls the "Not Racism ${ }^{\mathrm{TM}}$ " (52) gambit has of course many conduits, all of which narrow the terms by which racism can be identified and evaluated. A narrowing that leaves us only with comic book caricatures of hooded clansmen and goose-stepping neo-Nazis. Or leaves us only with those subaltern white denizens who lack the appropriate class resources or liberal discernment to moderate their racism with choice caveats ${ }^{1}$ or are foolish enough to visit violence upon non-white bodies (i.e. "hate crimes") as opposed to delegating it to the authorized imperatives of the police, border guards, or detention centres.

This "Not Racism" premise traffics of course in a double disavowal. It disavows racism insofar as it decrees racism to be risible, just as it disavows most of what actually constitutes racism in any sense beyond the most verboten individualized transgressions. This is a gambit that also relies on a further normative allowance wherein the adjudicating punditry, generally white and with their sinecures in the Establishment press, is entrusted with the task of judge and jury (55). This being an adjudicating theatre that has found it particularly convenient to operate under the voguish alibi of free speech "debatability" that has enamoured right-wing activism. "Debatability" (56), as expertly parsed by Gavan Titley (2019) and Sanjay Sharma (2013), speaks to that feature of our current media ecology where the auditing of racist scandal and incident has proven to be a particularly profitable media enterprise. Here, a racist incident is dutifully flagged. And thereupon, an already scripted set of strongly animated positions are to be adopted, not least the apologist brigade who are then invited to suggest, via assorted sophistries and pedantries, that the offending incident is not quite racism, that it is being overstated, that it is an isolated case, and any number of other trusted bromides. As Titley (2020) shows, the appeal to free speech proves a particularly dynamic device here, where many a grifter seems to think that they are obliged to speak in defense of racism, as a necessary exigency of free speech itself. Racism becomes in this format not a matter of human suffering and denigration to be redressed; but instead, racism becomes a discursive game, one that exercises the libidinal energies of outrage, contrarianism and apologia and is accordingly repeated on a transient basis for the media intensities it reliably generates.

The "Not Racism" era has herein many enablers, not least the nihilistic imperatives of the "attention economy" (Seymour 2019; Gilroy-Ware 2020) that governs profit-seeking digital media flow. But it is particularly the terms by which racisms can be clad in the distinctly romanticist garb of "mere" nationhood that has increasingly proven the more tenacious of the "it's not racism" ruses. It is this theme that I will accordingly centre in the 
remainder of my commentary, as not only does it chime with my own recent interests, but it also prizes open certain challenges as regards antiracist possibility in white majority settings.

\section{Ethnonationalism}

Lentin makes evident how apologists of racism routinely turn to the ontology of nation-state imaginations (79-92). Often drawing from a pseudo-psychological repertoire, comprising the putatively timeless truths of "in-group favoritism"(83) and the entrenched yearning for demographic cohesion, there is a strong appeal here to the immutable naturalness of nations desiring their own identity, their own sovereignty, and the retention of their cultural coherence, their traditions and their flattering narrations of history. There is an added intimation that the putative giving of preference to one's coethnics (read: majority white) is simply a form of "self-interest" (81) rooted in the properties of gemeinschaft. Today's revived politics of white grievance and revanchism are herein presented as simply a routine assertion of national desire and anxiety.

Such majoritarian conceits are of course common to all nationalisms conceits that mask the overdetermined animus, enmity, and defensive myopia that are otherwise centrifugal to a nationalist political sensibility. Similarly, the enduring imbrications of English and other analogous nationalisms with racist chauvinism hardly needs rehearsing here (Gilroy 1987; Shilliam 2018). But what is particularly grating is how the ability to abstract and absolve nationalism of its racial content also allows for increasingly effective deflections of emergent anti-racist generations more broadly. There is namely an increasingly crippling impasse that plagues the contemporary where any assertion of anti-racism is met by the counter-assertion of the sanctity of national culture and everyday patriotism.

Consider for instance the scenes in England in the wake of this summer's Black Lives Matter mobilization. Faced with an era-defining anti-racist uprising that Black Lives Matter represents, English conservatism sought refuge in the "culture wars" (Hirsch 2020). Seen from within these well-grooved trenches, the protests spoke not to the enduring field of Black suffering that Covid-19 had rendered so hauntingly visible: a disproportionality indexed by death, policing, and an outsize presence in parlous but underpaid and overexploited "frontline" jobs. Black Lives Matter is recast instead as a lifestyle politics exercised by a gratuitous iconoclasm and "cancel culture" that offend the sanctity of provincial, "blue wall" England. This purported "woke left modernism"2 denies the nation a beatifying history, but also, and rather more bathetically, the pleasures of noughties television - a prized cultural archive that, I have 
been reliably told, comprises gems such as Gavin And Stacey, Louis Walsh, and The Mighty Boosh.

That today's anti anti-racist might find it so straightforward to centre the validity of so-called "ethnotraditional nationalism" (86) as such a winning deflection is unsurprising. The play to the bluster and solace of nation allows for the effortless impugning of any attempt at an alternative politics. Not least, anti-racism. The appeal to bordering; the traducing of those who wish to interrogate the colonial archive that colour our museums, history books, and curricula; and the wholesale dismissal of younger generations who advocate for a progressive and indeed antiracist political perspective can all be justified as merely the upholding of the nation's autonomy and its people's supposedly humble desire for identity, tradition and cohesion. Here, racism is no longer something to be ideologically justified or defended; but instead, it is simply deflected through asserting the seemingly superseding dictates of national righteousness.

\section{Ruptures in the nation}

But what also interests me here is the potential weaknesses of this selfascribed "counter-hegemonic" (Ahmed 2008) mode of nationalist hegemony. As regards at least the politics of "Little Englander" (Gilroy et al. 2018) nationalism I am most familiar with, the defensiveness as modelled around the white conservative subject is in fact premised on the masochistic sensation of waging desperate battle against the tide of history and demographics. This is a politics of rearguard anxiety that styles itself as the voice of provincial white respectability versus deracinated metropolitan decadence. Its prevailing maxim, so invested in by Dominic Cummings, is that the fabled "silent majority" will always tell: that for every spectacular mobilization against prejudice and oppression comes a quiet shift towards aggrieved reaction among the non-vocal and largely white mass. The electoral triumphs of the last decade certainly vindicate such a calculus.

But also implicit here is an underlying and not entirely misplaced fear. A fear that demographics really are shifting (de Noronha 2020). A fear that culture and civic values are not as ossified in the imprint of national history and identity as they would like to believe. And a fear that the continued need to harangue and alienate in the name of white provincial communitarianism might risk provoking into being an oppositional majority - this being an otherwise unlikely majority where youthful radicalism meets the discontents of a beleaguered middle-class liberalism.

The young, who are as Keir Milburn (2019) argues increasingly a proxy for social class, represent a particularly formidable anxiety here. It is not sufficiently remembered that, even when generationally construed as all 
under-50s, the 2019 general election would have returned an eminently unlikely Corbyn victory. Contending with the end of the social mobility thesis, promised only a future of debt and rental dependency, and where the very notion of job security is a cruel anachronism, a much more combative generational disposition has taken root.

This is also a structurally squeezed generation that has been reared on a cultural diet that invites an oppositional stance. The more banal element of that diet comprises the saccharine but not entirely bankrupt supply of Netflix progressivism. But this also includes a wider political education as experienced via a routine familiarity with everyday urban multiculture; via incremental but still progressive shifts in university curricula; via algorithmically directed online commentary that favours indignant anger (of the altright variety, yes, but also of its critical inverse); and via a sequence of political causes that have periodically spluttered into view over the last decade. Consider here the formative legacies of Occupy, Corbynism, XR, Remain, Grenfell, Windrush, Me Too and the Women's Marches, but also, not least, the multiple iterations of Black Lives Matter.

This is, in other words, a generational tendency towards what Sita Balani (2020) calls an "ungovernable" irreverence that is also starting to make more assertive demands on older and often casually liberal parents and peers: those who were already unmoored by ruling conservatism's violent lurch towards authoritarian-nationalism, but who content themselves with the comforts of middle-class stability and status. This is namely a liberal affectation that often opts for the aesthetic satisfaction of a "moderation" (Müller 2018) that equivocates across different "extremisms" - a hollow centrism, as an end itself, where Corbyn and Johnson, antifascists and fascists, and rioters and tax dodgers could all be squared as corresponding ills. This is still probably the case. But it is also likely that the acute ongoing experience of the state's relative absence in the midst of a health and economic emergency, when compared to the example set in other countries, alongside a wider inability of the centre to hold a viable political ground, has for many lubricated a greater receptiveness (Shrimsley 2020) to the radical assertiveness of younger activists and opinion-makers.

I am of course engaging here in a willfully optimistic mode of conjunctural reflection, attempting almost in spite of myself to see in the dialectical shape of today's "white nationalisms" (Geary, Schofield, and Sutton 2020) a scope for new openings. To do so necessarily involves a deliberately naïve openness to the potential alignments that might be available in the contemporary. But doing so is also I think important in attempting to graft onto Lentin's very generative base a scope for thinking beyond the racisms of today and its multiple conduits, such as the politics of nation-craft. Lentin's book, by her own admission (171), is largely a sobering reassertion of the centrality of race and racism to our lives - a reassertion that is therefore less concerned with 
thinking through the gaps, contradictions and counter-currents that are constitutive of the same era. It is in this vein that I have accordingly tried to passingly press a suggestion that the spectacular recourse to a politics of racial nationalism in England, and elsewhere too, also presents certain structural contradictions where anti-racisms too might be finding renewed life.

\section{Chauvinism and dominance beyond whiteness}

Finally, whilst the wider imbrication of race with the nationalisms currently ascendant is fluently surveyed by Lentin, I wonder if the book's centrifugal emphasis on whiteness can be constructively unpacked through surveying a broader global canvas as regards the political ructions of today. Of course, the book's empirical remit is located firmly within certain iconic white majority settings (i.e. the US, UK, Australia and France). The "technologies" (63) of race-making as tied to the overarching coordinates of whiteness - e.g. assorted registers of entitlement and/or morbid nostalgia - become herein decisive to the upholding of today's political intensities. A politics of, amongst other things, rampantly Islamophobic populisms, frontier imperialisms, and/or the politics of walls and bordering that are multiplying all around us.

However, it is also evident that much of the above politics is also being enacted across various postcolonial settings - ranging from China, to India, to Myanmar, to Sri Lanka, to Turkey, and onward. Indeed, a politics of "majoritarian" (Chatterji, Hansen, and Jaffrelot 2019) aversion and disposability can seem today frankly immanent when considering its multiple global settings. It remains herein the case that the politics of borders and fortifications alongside related anti-minority and frontierist (Anand 2011; 2019) state practices are scarcely contained to white-majority settings. As Gargi Bhattacharyya (2018, 112) makes evident in her wider reading of a "racial capitalism" thesis, the logic of differentiation that capital has forged such an elective affinity with can be contoured by multiple interacting terms. In other words, the chauvinisms and divisions of race, nation and ethnicity, but also citizenship (de Noronha 2020) and internal citizenship (e.g. governing codifications as relevant for instance to internal migrant labour vis-à-vis the "sedentary" urban denizen in China [Chuang, 2020]) can often found to be doing a fairly comparable and mutually reinforcing work.

The wager of postcolonial thought (Mbembe 2008) is herein an important one, an intellectual and political wager that has steadfastly interrogated the limits of nation-making across various Global South contexts. This is accordingly a wager that might also constructively complicate the centring of race and whiteness as the only or primary ontic engine of the aforementioned political technologies. Instead, an expansive reading of racism but also cognate structures of communitarian exclusion and expendability might allow for a 
wider conceptual map consistent with the practices unfolding across multiple global settings. These being settings less touched by the pathologies of whiteness but where other invocations of nativism and communitarian majoritarianism can effect comparable outcomes.

Stuart Hall (2017), whose writing on colonial racism as well as racism's floating elasticity is generously engaged throughout the book, proves particularly giving here. His notion of a "fateful triangle" as operational across the race, ethnicity and nation nexus is for me an apposite device that helps map some of the wider similarities currently ravaging otherwise contrasting parts of the world - where a politics of nativism (N. Sharma 2020) and xenology (Bhatt 2012) intersect but without always calling upon a more ostensible logic of white supremacy as relevant to Western Europe and other comparable contexts. ${ }^{3}$

\section{Conclusion}

I end on this note not to dilute the vital and violent centrality of race that Lentin rightly profiles. Indeed, my own writing as relevant to England in our era of Brexit is just as invested in the centring of racism. But I wish to suggest that thinking through the wider frameworks of how racism interacts with the assorted nationalisms of today also opens up an instructive lens through which to establish the ethical bankruptcy of nationalism itself. This might seem a provincial emphasis, insofar as this is increasingly my own academic preoccupation. But I do think that a wider casting of nationalism's ability, via multiple registers of communitarianism, to disfigure any meaningfully progressive sense of human community, bond and openness is in itself useful. As it does also help better puncture the confidence of today's western commentariat who dress up the insularities and resentments of a whiteness in decline (Narayan 2017; Gilroy 2020) in the ostensibly more respectable clothing of ethnonationalism and identity.

I was once asked at an event about the particular challenges posed by the gathering storm of fascists who style themselves not as merchants of racethinking, but as romantic ethnonationalists, as champions of innocent identity, and as mere custodians of sovereignty. Whilst this is likely always a challenge, where ideological chicanery helps flatter the underlying aims and investments of reaction, what did seem remiss however was why such alternative alibis were being implicitly construed by the speaker as otherwise valid, noble, and even dignified. It is on these terms that I have increasingly thought it necessary to also repudiate the allegedly alternative projects that the alt-right and their establishment fellow travellers baldly insist upon. That is to say, ethnonationalism too is in on its own terms a futile and dehumanizing impasse, and is no less bad, no less comprised, even if it could manage to present itself as "simply" a politics of national identity and innocent majorities. 


\section{Notes}

1. Usually of the "I'm certainly not racist but ... ", "Islam is not a race ...", "being against immigration is not about race ...", etc.

2. See following tweet by the high-profile commentator, Matthew Goodwin: https://twitter.com/goodwinmj/status/1270824354901831683

3. The above also seems pertinent insofar as it is apparent that even in our white majority settings, many who are not themselves white are increasingly invited to adopt some of the rationales of racial aversion and suspicion that are central to today's nationalist-populisms. That the Tory front bench in Britain can be staffed by numerous high-profile Asian and Black figures seems no longer amenable to a more familiar analysis of tokenistic allowance. They are instead central voices in the shepherding of a punitive, Brexit-era jingoism as allied to the market-economics that is still the residual commitment of right-wing governance but no longer their ideological centrepiece. Similarly, that approximately a third of the "South Asian" vote [and presumably a much larger percentage of the non-Muslim "British Indian" vote, much of which is increasingly being interpellated through a resolutely petty-bourgeois conservative register (Shah 2020)] voted for Brexit does again require certain reflections (Gilroy 2020); this being, after all, a vote that was largely a proxy referendum on immigration. The terms by which the refugee but also the migrant more broadly might be denigrated as a threat to the nation's social fabric but also its economic vitality remains a set of rationales that many might find themselves persuaded by, including those who cannot readily claims the advantages of a hegemonically curated whiteness. Similarly, the terms by which the figure of the Muslim has come to a constitute a sort of overarching allochtoon, a sort of distinctively inassimilable and ominous world-historical Other, does also allow for many who are not themselves white to also accede to such demagogueries, and particularly so when we consider the rabid anti-Muslim politics that animates other non-western settings. Not least, the much commented upon consolidation of a Hindutva chauvinism in today's India.

\section{Disclosure statement}

No potential conflict of interest was reported by the author(s).

\section{References}

Ahmed, A. 2008. "Liberal Multiculturalism is the Hegemony - It's an Empirical Fact' - a Response to Slavoj Žižek." Darkmatter, February 19. http://www.darkmatter101.org/ site/2008/02/19/\%E2\%80\%98liberal-multiculturalism-is-the-hegemony-\%E2\%80\% 93-its-an-empirical-fact\%E2\%80\%99-a-response-to-slavoj-zizek/.

Anand, D. 2011. "China and India: Postcolonial Informal Empires in the Emerging Global Order." Rethinking Marxism 24 (1): 68-86.

Anand, D. 2019. "Colonization with Chinese Characteristics: Politics of (in)Security in Xinjiang and Tibet." Central Asian Survey 38 (1): 129-147.

Balani, S. 2020. "Making it Count: Resisting the Authority of Ignorance." Ceasefire, June 10. https://ceasefiremagazine.co.uk/making-it-count-resisting-the-authority-of-ignorance/. 
Bhatt, C. 2012. "The New Xenologies of Europe: Civil Tensions and Mythic Pasts." Journal of Civil Society 8 (3): 307-326.

Bhattacharyya, G. 2018. Rethinking Racial Capitalism: Questions of Reproduction and Survival. London: Rowman \& Littlefield.

Bhattacharyya, G. 2020. "We, the Heartbroken." Pluto Books Blogs, December 3. https:// www.plutobooks.com/blog/we-the-heartbroken/.

Chatterji, A. P., T. B. Hansen, and C. Jaffrelot. 2019. Majoritarian State: How Hindu Nationalism is Changing India. Oxford: Oxford University Press.

Chuang 2020. "Free to Move, Forced to Move: The Present State of the Hukou System." Chuang Collective Blogs, May 18. https://chuangen.org/2020/05/free-to-move/.

Clifford, J. 2000. "Taking Identity Politics Seriously: 'The Contradictory, Stony Ground ...'." In Without Guarantees: In Honour of Stuart Hall, edited by P. Gilroy, L. Grossberg, and A. McRobbie, 94-112. London: Verso.

de Noronha, L. 2020. Deporting Black Britons: Portraits of Deportation to Jamaica. Manchester: Manchester University Press.

Geary, D., C. Schofield, and J. Sutton. 2020. Global White Nationalism: From Apartheid to Trump. Manchester: Manchester University Press.

Gilroy, P. 1987[2002]. There Ain't No Black in the Union Jack. London: Routledge Classics. Gilroy, P. 2020. "Paul Gilroy: 'Whiteness Just Ain't Worth What it Used to Be'." Nation, October 28. https://www.thenation.com/article/culture/paul-gilroy-interview/.

Gilroy, P., T. Sandset, S. Bangstad, and G. R. Høibjerg. 2018. "A Diagnosis of Contemporary Forms of Racism, Race and Nationalism: A Conversation with Professor Paul Gilroy." Cultural Studies 33 (2): 173-197.

Gilroy-Ware, M. 2020. After the Fact? The Truth About Fake News. London: Repeater Books.

Goldberg, D. T. 2015. Are We All Postracial Yet? Cambridge: Polity Press.

Hall, S. 2017. Fateful Triangle: Race, Ethnicity, Nation. Cambridge, MA: Harvard University Press.

Hirsch, A. 2020. "Boris Johnson Does Have a Strategy on Racism After All. It's called a 'war on woke'." Guardian, June 17. https://www.theguardian.com/commentisfree/ 2020/jun/17/boris-johnson-racism-woke-tories.

Kumar, A., D. Gebrial, A. Elliott-Cooper, and S. lyer. 2018. "Introduction: Marxist Interventions Into Contemporary Debates." Historical Materialism 26: 2. https:// www.historicalmaterialism.org/index.php/articles/marxist-interventions-intocontemporary-debates.

Lentin, A. 2020. Why Race Still Matters. Cambridge: Polity Press.

Lentin, A., and G. Titley. 2011. The Crises of Multiculturalism: Racism in a Neoliberal Age. London: Zed Books.

Mbembe, A. 2008. "What is Postcolonial Thinking?" Eurozine, January 9. https://www. eurozine.com/what-is-postcolonial-thinking/.

Mbembe, A. 2017. Critique of Black Reason. Durham, NC: Duke University Press.

Milburn, K. 2019. Generation Left. Cambridge: Polity Press.

Müller, J.-W. 2018. "What Cold War Liberalism Can Teach Us Today." New York Review of Books, November 26. https://www.nybooks.com/daily/2018/11/26/what-cold-warliberalism-can-teach-us-today/.

Narayan, J. 2017. "The Wages of Whiteness in the Absence of Wages: Racial Capitalism, Reactionary Intercommunalism and the Rise of Trumpism." Third World Quarterly 38 (11): 2482-2500.

Richmond, M. 2020. “Anti-Racism as Procedure." Protocols, December 15. https://prtcls. com/article/richmond_labour-antisemitism/. 
Seymour, R. 2019. The Twittering Machine. London: Indigo Press.

Shah, N. 2020. "How did British Indians Become so prominent in the Conservative Party?" Guardian, February 27. https://www.theguardian.com/commentisfree/ 2020/feb/27/how-did-british-indians-become-so-prominent-in-the-conservativeparty.

Sharma, S. 2013. "Black Twitter? Racial Hashtags, Networks and Contagion." New Formations 78: 46-74.

Sharma, N. 2020. Home Rule: National Sovereignty and the Separation of Natives and Migrants. Durham, NC: Duke University Press.

Shilliam, R. 2018. Race and the Undeserving Poor. Newcastle upon Tyne: Agenda Publishing.

Shrimsley, R. 2020. "Boris Johnson Cannot Substitute Culture Wars for Competence." Financial Times, June 22. https://www.ft.com/content/e09c6f83-d591-4c65-a02cd3863034fdb3?

Táíwò, O. O. 2020. "Being-in-the-Room Privilege: Elite Capture and Epistemic Deference." The Philosopher 108: 4. https://www.thephilosopher1923.org/essaytaiwo.

Titley, G. 2019. Racism and Media. London: Sage.

Titley, G. 2020. Is Free Speech Racist? Cambridge: Polity Press. 